\title{
Does polycystic ovary syndrome with phenotype $D$ affect the cardiovascular endurance, core endurance, body awareness, and the quality of life? A prospective, controlled study
}

\author{
Fenotip D'li polikistik over sendromu kardiyovasküler \\ enduransı, kor enduransı, vücut farkındalığını ve yaşam \\ kalitesini etkiler mi? Prospektif, kontrollü çalışma
}

\author{
(D) Hanife Doğan ${ }^{1}$, (1) Melike Demir Çaltekin² \\ ${ }^{1}$ Yozgat Bozok University, Sarkaya School of Physiotherapy and Rehabilitation, Yozgat, Turkey \\ 2 Yozgat Bozok University Faculty of Medicine, Department of Gynecology and Obstetrics, Yozgat, Turkey
}

\begin{abstract}
Objective: This study evaluates cardiovascular endurance, core endurance, body awareness, and the quality of life in normal-weight women with polycystic ovary syndrome.

Materials and Methods: This study included a total of 101 normal-weight women ( 51 with and 50 without polycystic ovary syndrome). Cardiovascular endurance was evaluated with the 20-meter Shuttle Run test, and maximum oxygen consumption was calculated. Core endurance was evaluated with core stability tests, body awareness with the body awareness questionnaire, and the quality of life with short form-36. Blood lipids, glucose, insulin, homeostatic model assessment for insulin resistance (HOMA-IR), hormonal profile, and high-density and low-density lipoprotein cholesterols were measured. Results: Maximum oxygen consumption, core endurance, body awareness questionnaire, and short form-36 results were lower in women with polycystic ovary syndrome than healthy women $(\mathrm{p}<0.05)$. There was a significant correlation between core endurance tests, high-density lipoprotein cholesterol, maximum oxygen consumption, and homeostatic model assessment for insulin resistance scores $(\mathrm{p}<0.05)$.

Conclusion: When normal-weight women with polycystic ovary syndrome and control groups with similar androgen levels and body mass index profiles were compared, women with polycystic ovary syndrome had lower aerobic capacity and muscle endurance. This suggests that the adverse metabolic profile of polycystic ovary syndrome can limit physical function.

Keywords: Polycystic ovary syndrome, exercise tolerance, core stability, body image

Öz

Amaç: Bu çalışmada, normal kilolu polikistik over sendromlu kadınların kardiyovasküler enduransının, kor enduransının, vücut farkındalığının ve yaşam kalitesinin değerlendirilmesi amaçlandı.

Gereç ve Yöntemler: Bu çalışmaya toplam 101 normal kilolu kadın (51 polikistik over sendromlu ve 50 polikistik over sendromsuz) dahil edildi. Kardiyovasküler endurans, 20 metrelik Shuttle Run testi ile değerlendirildi ve maksimum oksijen tüketimi hesaplandı. Kor enduransları kor stabilite testleri ile, vücut farkındalığı vücut farkındalık anketi ile, yaşam kaliteleri kısa form-36 ile değerlendirildi. Kan lipidleri, glukoz, insülin, homeostatik model değerlendirmesi (HOMA-IR), hormon profilleri ve yüksek yoğunluklu ve düşük yoğunluklu lipoprotein kolosterol ölçüldü.

Bulgular: Polikistik over sendromlu kadınlarda maksimum oksijen tüketimi, kor endurans, vücut farkındalık anketi ve kısa form-36 sonuçları sağlıklı kadınlara göre daha düşüktü $(\mathrm{p}<0,05)$. Kor endurans testleri ile yüksek yoğunlujlu, lipoprotein kolesterol, maksimum oksijen tüketimi ve homeostatik model değerlendirmesi insülin direnci skorları arasında anlamlı bir ilişki vardı $(\mathrm{p}<0,05)$.
\end{abstract}

PRECIS: We evaluated cardiovascular endurance (CE), core endurance, body awareness, and the quality of life in normal-weight women with phenotype D-polycystic ovary syndrome (PCOS) and healthy women.

Address for Correspondence/Yazışma Adresi: Asst. Prof. Hanife Doğan,

Yozgat Bozok University, Sarkaya School of Physiotherapy and Rehabilitation, Yozgat, Turkey

Phone: +90 5075346142 E-mail: hanife.dogan@yobu.edu.tr ORCID ID: orcid.org/0000-0002-2294-2483

Received/Geliș Tarihi: 30.05.2021 Accepted/Kabul Tarihi: 20.06.2021

${ }^{\oplus}$ Copyright 2021 by Turkish Society of Obstetrics and Gynecology

Turkish Journal of Obstetrics and Gynecology published by Galenos Publishing House 
Sonuç: Polikistik over sendromlu normal kilolu kadınlar ile androjen düzeyleri ve vücut kütle indeks profilleri benzer olan kontrol grupları karşılaştırıldığında, polikistik over sendromlu kadınların aerobik kapasiteleri ve kas enduransları daha düşüktü. Bu, polikistik over sendromun olumsuz metabolik profilinin fiziksel işlevi sınırlayabileceğini düşündürmektedir.

Anahtar Kelimeler: Polikistik over sendromu, egzersiz toleransı, kor stabilite, beden imajı

\section{Introduction}

Polycysticovarysyndrome(PCOS)affects 6-10\% of reproductiveaged women. PCOS is a common endocrinological disease that can have progressive metabolic effects ${ }^{(1)}$. Hyperandrogenism, ovulatory dysfunction, dyslipidemia, and insulin resistance (IR) are the principal features of this syndrome ${ }^{(2)}$. Also, women with PCOS have more cardiovascular risk factors, such as dyslipidemia, hypertension, glucose intolerance, and diabetes, compared with women without PCOS ${ }^{(2-4)}$.

The maximal oxygen consumption (VO2max) is the highest amount of oxygen used by the body during maximal exercise, and the risk of cardiovascular disease increases when VO2max is reduced. Studies are contradictory about whether PCOS affects $\mathrm{VO} 2 \max$. One study(4) stated that $\mathrm{VO} 2 \max$ values of women with and without PCOS were similar. A second study ${ }^{(4)}$ found that VO2max values of women with PCOS were lower than those without PCOS.

In addition to the change in V02max, muscle function may also be affected by biochemical results in PCOS. Insulin is the primary regulator of muscle proteins. It can stimulate mitochondrial protein synthesis ${ }^{(2)}$. Androgens can increase muscle strength or endurance and may promote free-fat muscle growth. When the amount of high-density lipoprotein cholesterol (HDL) decreases, it can decrease muscular function by increasing the release of proinflammatory cytokines ${ }^{(5-7)}$. Core endurance is a muscle function (abdominal, paraspinal, gluteal, diaphragm, and pelvic floor muscles) PCOS can affect core muscles due to impaired biochemical profiles ${ }^{(8-10)}$.

The endurance of the core muscles and the cardiorespiratory system are among the parameters of physical function. Body awareness informs the individual of the relationship between physical function and mental activity and explains how these factors affect the body. Alexander stated that the change in muscular functions decreases physical awareness and information from the body ${ }^{(8,9)}$. Based on studies showing changes in these factors ${ }^{(2-5,11,12)}$, PCOS may also affect the body awareness. In addition, the change in the appearance of women with PCOS, infertility, decrease in performance, and cardiovascular disease risk may affect their quality of life (QOL) $(13,14)$.

To the best of our knowledge, there are no studies comparing women with and without PCOS regarding VO2max, core endurance, QOL, and body awareness ${ }^{(5)}$. Studies on PCOS have mainly been conducted on obese women ${ }^{(4,8,11,12-18)}$. We wanted to exclude the obesity factor to examine the effect of PCOS. The present study evaluates VO2max, core endurance, body awareness, and QOL in normal-weight women with and without PCOS and investigate the effect of PCOS on these parameters.

\section{Materials and Methods}

\section{Study Design and Participants}

This case-control study was conducted prospectively in the gynecology department of a tertiary hospital. Also, permission was granted from the Clinical Research Ethics Committee of the University before the study (decision no: 2017-KAEK189_2020.01.08_04). All participants were informed about the study based on the 1975 Helsinki Declaration. All participants also signed informed consent that they agreed to participate in the study.

Inclusion criteria were weight stability $(<2.0 \mathrm{~kg}$ weight changes) for the last 3 months, 18-40 years of age, willingness to participate in the study, and having normal weight [body mass index (BMI): $18.5-24.99 \mathrm{~kg} / \mathrm{m}^{2}$ ]. The exclusion criteria for both groups included smoking, volunteers who performed regular exercise, cardiovascular and chronic diseases, androgensecreting tumors, late-onset 21-hydroxylase deficiency, drugs (such as hormones, anti-diabetic agents, and oral contraceptives), and pregnancy. Participants with a history of angina or any other cardiopulmonary or physical symptoms that could affect exercise performance were also excluded ${ }^{(12)}$.

The diagnosis of PCOS was made according to the Rotterdam criteria $^{(19)}$ : those with two of the three criteria were diagnosed as PCOS: oligo and/or anovulation ( $>35$ days or $<8$ spontaneous menstruation/year), biochemical and/or clinical (FerrimanGallwey score $>8$ ) hyperandrogenism, and polycystic ovary (12 or more follicles 2-9 $\mathrm{mm}$ in diameter in each ovary and/or ovarian volume $>10 \mathrm{~mL}$ ). We included only phenotype D-PCOS women in our study, as hyperandrogenism may affect muscle strength. In our study, the women in the PCOS group were identified according to the specific European Society for Human Reproduction and Embryology and the American Society for Reproductive Medicine phenotypes as type D: oligo and/or anovulation and polycystic ovary ${ }^{(20)}$. Patients who applied for routine gynecological examination without oligomenorrhea and did not meet the PCOS diagnostic criteria were included in the control group ${ }^{(5)}$.

According to the reference study results, they had a large effect size $(\mathrm{d}=0.71)^{(5)}$. Assuming we could achieve a lower effect size level $(\mathrm{d}=0.5)$, a power analysis was performed before the study. Accordingly, when at least 100 participants 50 from the PCOS group and 50 from the control group) were included in the study, which would result in $80 \%$ power with a $95 \%$ confidence level (5\% type 1 error rate). 


\section{Evaluations}

Demographic characteristics [age (years), education (primary school, high school, or university), and employment status (yes or no)] were questioned, and waist-hip ratio (WHR) was calculated.

Ultrasonography: Morphological features of the ovaries of all participants were examined by transabdominal/transvaginal ultrasonography (GE Voluson E8, USA) ${ }^{(4,12)}$.

Biochemical analysis: Blood samples were collected on the second or third days of the menstrual cycle. Serum insulin, luteinizing hormone, follicle-stimulating hormone, and total testosterone levels were measured via electrochemiluminescence immunoassay on a Roche COBAS 6000 e601 (Roche Diagnostics, Mannheim, Germany) autoanalyzer. Fasting glucose, total cholesterol (TC), high-density lipoprotein cholesterol (HDL-C), and triglyceride (TG) levels were analyzed on a Roche COBAS 6000 c501 (Roche Diagnostics) autoanalyzer. Low-density lipoprotein cholesterol (LDL-C) was calculated using the Friedewald formula when the TG level was less than $400 \mathrm{mg} / \mathrm{dL}$. Homeostatic model assessment for insulin resistance (HOMAIR) was used to calculate IR. HOMA-IR (fasting blood glucose $\mathrm{mg} / \mathrm{dL} x$ fasting insulin $\mathrm{mIU} / \mathrm{L} / 405$ ) value $\geq 2.5$ was accepted as the presence of $\operatorname{IR}^{(3,4,19)}$.

Cardiorespiratory endurance: The cardiovascular endurance level (VO2max) of all participants was evaluated with the 20 -meter shuttle run test $(20 \mathrm{mSRT})^{(8,21)}$. This test was developed in accordance with the Eurofit test Battery (1988) directives. In the 20mSRT, the participants ran continuously on a 20-m-track at an initial speed of $8 \mathrm{~km} / \mathrm{h}$, which increased $0.5 \mathrm{~km} / \mathrm{h}$ per one minute. The running pace was adjusted using a timer and signal generator. The women who took the test were asked to complete the 20-m-course at each signal. The test was terminated for women unable to reach the lines one meter before the lines that determined the 20 meters when the signal was received. The running pace in accordance with the test protocol was provided by the signals obtained from the Pro Tmr Esc 1000 sport test timer ${ }^{(21,22)}$. VO2max levels in mL/kg/ min were calculated using Leger's formula ${ }^{(23)}$ :

$\mathrm{VO} 2$ peak $=31.025+3.238 * \mathrm{~S}-3.248 * \mathrm{~A}+0.1536 * \mathrm{~S} * \mathrm{~A}$

$\mathrm{S}=$ final speed (kmh-1); $\mathrm{A}=$ age (years).

Core endurance: A protocol developed by McGill was used to assess the endurance of the core muscles. Core endurance was evaluated with a core stability test (trunk flexion, extension, and lateral right/left bridge tests). In the trunk flexion test (TFT), the participants were seated on the treatment table with a wedge that provided a $45^{\circ}$ flexion on their back. The knees were brought to $90^{\circ}$ flexion. The test was ended when the upper body could not maintain the $45^{\circ}$ angle (Figure 1a). In the trunk extensor endurance test (TEET), the participants were asked to lie on the treatment table in the prone position. In the prone position, the spina iliaca anterior superior part of the participant was placed on the edge of the table. The body was suspended from the table (Figure 1b). The lateral bridge test (RBT/LBT): Participants were asked to build a side bridge by standing on the forearms with the elbow flexed at $90^{\circ}$ in the side-lying position. They were also instructed to lift the hip off the table with the other arm and hand. The test was terminated when the straight body position could not be maintained. This test was repeated for both the right and left sides separately. The time to maintain these positions was recorded (Figure 1c) $(10,24,25)$.

Body awareness: Participants' body awareness was evaluated using the body awareness questionnaire (BAQ) developed by Shieldsetal. ${ }^{(26)}$ Turkish validity and reliability of the questionnaire were carried out by Karaca and Bayar(27) Participants' body awareness was evaluated using the $\mathrm{BAQ}^{(13)}$. BAQ aims to evaluate cases with sensitivity to body cycles and rhythms, the ability to perceive minor changes in normal functioning, and the ability to predict bodily responses. BAQ consists of 18 items and 4 subdimensions. The four subdimensions are as follows: body reactions estimation (BAQ-I), sleep-wake cycle (BAQ-II), prediction at the onset of the disease (BAQ-III), and paying attention to the changes in body processes and reactions (BAQ-IV). Each of the 18 expressions is scored between 1 and $7(1=\text { Not at all true about me, } 7=\text { Very true about me })^{(26)}$. The higher the score obtained from the questionnaire, the higher the level of body awareness.

QOL: Participants' QOL was evaluated using the short form36 (SF-36) scale ${ }^{(28)}$. Turkish validity and reliability of the scale were conducted by Koçyiğit et al. ${ }^{(28)}$ in 1994. The SF-36 consists of 36 items and eight subdimensions. Physical function, role restriction due to physical problems, role restriction due to emotional problems, mental health perception, social function, general health perception, body pain, and vitality comprised the subdimensions. The scoring of each section was between 0 and 100. Zero indicated the lowest QOL, whereas 100 indicated the highest QOL ${ }^{(14)}$

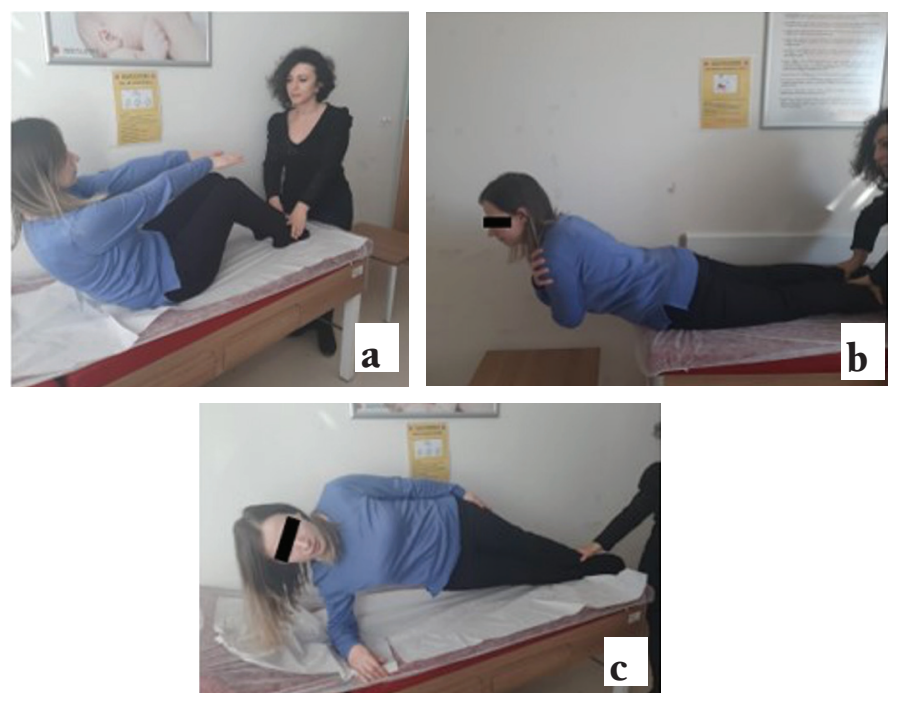

Figure 1a. Trunk flexor bridge test, b. Trunk extensor bridge test, c. Left/right side bridge test 


\section{Statistical Analysis}

All statistical analyses were performed using SPSS 25.0 software. Continuous variables were defined by the mean \pm standard deviation, median (minimum-maximum values), and categorical variables were defined by number and percent. The Kolmogorov-Smirnov test was used for the determination of normal distribution. For independent group comparisons, an independent samples t-test was used when parametric test assumptions were provided. The Mann-Whitney U test was used when parametric test assumptions were not provided. A Spearman correlation analysis was performed to analyze the relationships between continuous variables. The effect of PCOS on continuous variables was determined by linear regression analysis models using dummy variables. Statistical significance was determined as $\mathrm{p}<0.05$.

\section{Results}

In the present study, 101 women [control group (50 women) and PCOS group (51 women)] were included in the study. Their demographic information is provided in Table 1. There was no significant difference in women's age, education, BMI, and occupation status between the groups ( $p>0.05$ ).

The comparison of the biochemical results, VO2max, core endurance tests, BAQ, and the SF-36 scores are shown in Table 2. WHR and HOMA-IR index variables were higher in the PCOS group compared with the control group $(\mathrm{p}<0.05)$. HDL-C, VO2max, TFT, TEET, RBT and LBT, BAQ-total, BAQ-I, BAQII, BAQ-IV, physical function, physical role limitations, vitality, mental, pain, and general health scores of the PCOS group were lower compared with those of the control group $(\mathrm{p}<0.05)$.

The correlations of the biochemical results, VO2max, and core endurance are shown in Table 3. A positive correlation

Table 1. Demographic characteristics of participants

\begin{tabular}{|c|c|c|c|}
\hline & $\begin{array}{l}\text { Control } \\
(n=50)\end{array}$ & $\begin{array}{l}\text { PCOS } \\
(n=51)\end{array}$ & $\mathrm{p}$ \\
\hline Age $(y)^{*}$ & $25(18-34)$ & $24(18-38)$ & $0.27(z=-1.10)$ \\
\hline BMI $\left(\mathrm{kg} / \mathrm{m}^{2}\right)^{* * *}$ & $22.7 \pm 1.33$ & $23.0 \pm 1.12$ & $\begin{array}{l}0.317(\mathrm{t}=3.568) \\
\text { Total }\end{array}$ \\
\hline \multicolumn{4}{|c|}{ Education status** $0.88\left(\chi^{2} 0.24\right)$} \\
\hline Primary education & $1(2 \%)$ & $1(2 \%)$ & $2(2 \%)$ \\
\hline High school & $19(38 \%)$ & $17(33.3 \%)$ & $36(35.6 \%)$ \\
\hline University & $30(60 \%)$ & $33(63.7 \%)$ & $63(62.4 \%)$ \\
\hline \multicolumn{4}{|c|}{ Occupation $^{* *} 0.622\left(\chi^{2} 0.24\right)$} \\
\hline Worker & $25(50 \%)$ & $23(45.1 \%)$ & $48(47.5 \%)$ \\
\hline Housewife & $25(50 \%)$ & $28(54.9 \%)$ & $53(52.5 \%)$ \\
\hline
\end{tabular}

Table 2. Biochemical analyses, core endurance tests, body awareness, and the quality of life of participants

\begin{tabular}{|c|c|c|c|}
\hline & Control $(n=50)$ & $\operatorname{PCOS}(n=51)$ & p \\
\hline WHR & $\begin{array}{l}0.8 \\
(0.64-1.07)\end{array}$ & $\begin{array}{l}0.85 \\
(0.69-1.37)\end{array}$ & $\begin{array}{l}0.0001^{*} \\
(z=-4.748)\end{array}$ \\
\hline HDL-C (mg/dL) & $61.55 \pm 15.43$ & $49.17 \pm 9.37$ & $\begin{array}{l}0.0001^{*} \\
(\mathrm{t} 4.882)\end{array}$ \\
\hline LDL-C (mg/dL) & $\begin{array}{l}90 \\
(20.98-159)\end{array}$ & $\begin{array}{l}88.42 \\
(35-214.4)\end{array}$ & $\begin{array}{l}0.555 \\
(z=-0.591)\end{array}$ \\
\hline $\begin{array}{l}\text { HOMA-IR (mg/dL } \\
\left.{ }^{x} \mu \mathrm{U} / \mathrm{mL}\right)\end{array}$ & $\begin{array}{l}1.79 \\
(0.69-3.64)\end{array}$ & $\begin{array}{l}2.81 \\
(0.86-7.1)\end{array}$ & $\begin{array}{l}0.0001^{*} \\
(z=-4.790)\end{array}$ \\
\hline $\begin{array}{l}\text { Triglycerides } \\
(\mathrm{mmol} / \mathrm{L})\end{array}$ & $\begin{array}{l}67.45 \\
(18.4-272)\end{array}$ & $\begin{array}{l}75 \\
(32.1-377)\end{array}$ & $\begin{array}{l}0.055 \\
(z=-1.922)\end{array}$ \\
\hline $\begin{array}{l}\text { Total cholesterol } \\
(\mathrm{mmol} / \mathrm{L})\end{array}$ & $\begin{array}{l}148.45(84.5- \\
259)\end{array}$ & $\begin{array}{l}153 \\
(102.4-269)\end{array}$ & $\begin{array}{l}0.257 \\
(z=-1.134)\end{array}$ \\
\hline $\begin{array}{l}\text { VO2max } \\
\text { (mL/kg/minute) }\end{array}$ & $\begin{array}{l}24.7 \\
(19-27.5)\end{array}$ & $\begin{array}{l}23.2 \\
(22-25.4)\end{array}$ & $\begin{array}{l}0.02^{*} \\
(z=-2.332)\end{array}$ \\
\hline $\begin{array}{l}\text { Total testosterone } \\
(\mathrm{ng} / \mathrm{mL})\end{array}$ & $\begin{array}{l}0.31 \\
(0.1-0.62)\end{array}$ & $\begin{array}{l}0.32 \\
(0.12-0.69)\end{array}$ & $\begin{array}{l}0.691 \\
(z=-0.398)\end{array}$ \\
\hline \multicolumn{4}{|l|}{ Core stability tests } \\
\hline TFT (s) & $42(8-93)$ & $22(14-42)$ & $\begin{array}{l}0.0001^{*} \\
(z=-8.035)\end{array}$ \\
\hline TEET (s) & $86(40-120)$ & $21(10-60)$ & $\begin{array}{l}0.0001^{*} \\
(z=-8.513)\end{array}$ \\
\hline RBT (s) & $37(12-96)$ & $17(8-48)$ & $\begin{array}{l}0.0001^{*} \\
(z=-6.807)\end{array}$ \\
\hline LBT (s) & $38(17-153)$ & $17(7-30)$ & $\begin{array}{l}0.0001^{*} \\
(z=-8.358)\end{array}$ \\
\hline \multicolumn{4}{|l|}{ BAQ } \\
\hline BAQ-total & $90.5 \pm 11.12$ & $73.12 \pm 4.42$ & $\begin{array}{l}0.0001^{*} \\
(\mathrm{t}=10.360)\end{array}$ \\
\hline BAQ-I & $37(23-45)$ & $28(20-40)$ & $\begin{array}{l}0.0001^{*} \\
(z=-7.326)\end{array}$ \\
\hline BAQ-II & $34(26-42)$ & $28(24-37)$ & $\begin{array}{l}0.0001^{*} \\
(z=-6.233)\end{array}$ \\
\hline BAQ-III & $16(10-20)$ & $16(13-19)$ & $\begin{array}{l}0.056(z=- \\
1.915)\end{array}$ \\
\hline BAQ-IV & $26(14-33)$ & $21(16-26)$ & $\begin{array}{l}0.0001^{*} \\
(z=-5.197)\end{array}$ \\
\hline
\end{tabular}

SF-36

$\begin{array}{llll}\begin{array}{l}\text { Physical function } \\ 87.5(60-100)\end{array} & 75(60-100) & \begin{array}{l}0.0001^{*} \\ (\mathrm{z}=-4.656)\end{array} \\ \begin{array}{l}\text { Physical role } \\ \text { difficulty }\end{array} & 100(0-100) & 75(50-100) & \begin{array}{l}0.0001^{*} \\ (\mathrm{z}=-5.895)\end{array} \\ \begin{array}{l}\text { Emotional role } \\ \text { difficulty }\end{array} & 66(0-100) & 66(0-100) & \begin{array}{l}0.745 \\ (\mathrm{z}=-0.326)\end{array} \\ \text { Vitality } & 60(30-85) & 55(40-80) & \begin{array}{l}0.001^{*} \\ (\mathrm{z}=-3.269)\end{array} \\ \text { Mental health } & 68.98 \pm 12.91 & 54.47 \pm 10.62 & \begin{array}{l}0.0001^{*} \\ (\mathrm{t}=6.173)\end{array} \\ \text { Social function } & \begin{array}{l}75 \\ (37.5-100)\end{array} & 75(25-100) & \begin{array}{l}0.136 \\ (\mathrm{z}=-1.491)\end{array} \\ \text { Pain } & 77.5 & 75(45-100) & \begin{array}{l}0.0001^{*} \\ (\mathrm{z}=-3.502)\end{array} \\ \text { General health } & 67.5(50-100) & 60(40-85) & \begin{array}{l}0.002^{*} \\ (\mathrm{z}=-3.061)\end{array}\end{array}$

WHR: Waist-hip ratio, HOMA-IR: Homeostatic model assessment for insulin resistance, s: Second, SF: Short-form, BAQ: Body awareness questionnaire, BAQ-I (anticipation of bodily reactions); BAQ-II (sleep-wake cycle), BAQ-III (anticipation at the onset of the disease), and BAQ-IV (changes in body process), TFT: Trunk flexion test, TEET: Trunk extensor endurance test, LBT: Lateral left bridge test, RBT: Lateral right bridge test, mL: Milligram, dL: Deciliter, mL: Milliliter, HDL-C: High-density lipoprotein cholesterol, LDL-C: Low-density lipoprotein cholesterol, PCOS: Polycystic ovary syndrome, Data is shown as median (minimum-maximum) and mean \pm standard deviation, *Mann-Whitney U test $(\mathrm{z}),{ }^{* * *}$ Independent Samples t-test $(\mathrm{t})$ 
Table 3. Correlations between VO2max, core stability, and biochemical analyses variables

\begin{tabular}{|c|c|c|c|c|c|}
\hline & & \multicolumn{4}{|c|}{ All patients } \\
\hline & & WHR & HDL-C & HOMA-IR & Triglyceride \\
\hline & & & (mg/dL) & $(\mathrm{mg} / \mathrm{dL} \times \mu \mathrm{U} / \mathrm{mL})$ & $(\mathrm{mmol} / \mathrm{L})$ \\
\hline \multirow{2}{*}{$\mathrm{VO} 2 \mathrm{max}(\mathrm{mL} / \mathrm{kg} /$ minute $)$} & r & -0.351 & 0.455 & -0.444 & -0.207 \\
\hline & $\mathrm{p}$ & 0.000 & 0.000 & 0.000 & 0.038 \\
\hline \multirow{2}{*}{ TFT (s) } & r & -0.459 & 0.525 & -0.505 & -0.277 \\
\hline & $\mathrm{p}$ & 0.000 & 0.000 & 0.000 & 0.005 \\
\hline \multirow{2}{*}{ TEET (s) } & r & -0.498 & 0.472 & -0.425 & -0.172 \\
\hline & $\mathrm{p}$ & 0.000 & 0.000 & 0.000 & 0.086 \\
\hline \multirow{2}{*}{ RBT (s) } & r & -0.480 & 0.462 & -0.457 & -0.192 \\
\hline & $\mathrm{p}$ & 0.000 & 0.000 & 0.000 & 0.055 \\
\hline \multirow[t]{2}{*}{ LBT (s) } & $\mathrm{r}$ & -0.422 & 0.432 & -0.489 & -0.213 \\
\hline & $\mathrm{p}$ & 0.000 & 0.000 & 0.000 & 0.032 \\
\hline
\end{tabular}

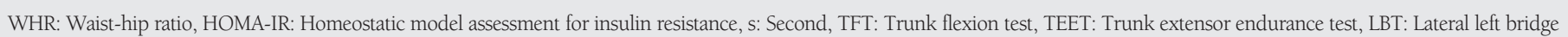
test, RBT: Lateral right bridge test, mg: Milligram, dL: Deciliter, mL: Milliliter, HDL-C: High-density lipoprotein cholesterol, r: Spearman correlation

was found between HDL-C and VO2max, TFT, TEET, RBT, and LBT scores $(\mathrm{p}<0.001)$. There was a negative correlation between VO2max and HOMA-IR, WHR, and triglyceride values $(p<0.05)$. A negative correlation was found between TFT and WHR, HOMA-IR, and triglyceride values $(\mathrm{p}<0.05)$. A negative correlation was found between TEET and WHR and HOMAIR values $(p<0.001)$. A negative correlation was found between RBT and WHR, LDL-C, HOMA-IR, and TC values ( $<<0.05)$. Correlations of VO2max, core endurance, body awareness, and QOL scores are shown in Table 4. A moderate negative correlation was found between BAQ-III and VO2max $(p<0.05)$. A weak positive correlation was found between TEET and vitality and BAQ-II results $(\mathrm{p}<0.05)$. A moderate positive correlation was found between mental function and VO2max $(\mathrm{p}<0.05)$.

Considering these differences, the factors that affected the PCOS factor were investigated. PCOS decreased HDL-C, HOMA-IR, TFT, TEET, RBT, LBT, BAQ-total, BAQ-I, BAQ-II, BAQ-IV, physical function, physical role limitation, vitality, mental, pain, and general score variables (standard beta values, from -0.910 to -276). Also, PCOS had an increasing effect on the HOMA-IR index and BAQ-III variables (Table 5).

\section{Discussion}

This study showed that normal-weight PCOS women with phenotype D had a lower cardiovascular endurance, core endurance, body awareness, and QOL than the women in the control group. To the best of our knowledge, this is the first study investigating the effect of normal weight in PCOS on these factors.

Many studies in the literature compare cardiovascular performance and QOL in PCOS ${ }^{(1-4,16)}$. However, these studies were primarily conducted on obese women ${ }^{(4,16,28)}$. In one of these studies ${ }^{(16)}$, the mean BMI was $39.9 \pm 6.1 \mathrm{~kg} / \mathrm{m}^{2}$, while in another study, the mean BMI values were $34.1 \pm 5.5$ in PCOS and $35.5 \pm 4.9 \mathrm{~kg} / \mathrm{m}^{2}$ in the control group ${ }^{(4)}$. In the present study, the BMI of women with and without PCOS were $23.4 \pm 0.97$ and $22.6 \pm 1.10 \mathrm{~kg} / \mathrm{m}^{2}$, respectively. This study was the first study planned within normal BMI limits.

In one study ${ }^{(4)}$, VO2max was evaluated, and its relationship with hormonal and metabolic factors was investigated. Another study ${ }^{(12)}$ compared metabolic heart rate and VO2max factors in women with and without PCOS. In the present study, many factors that might affect the lifestyle in PCOS were investigated more comprehensively than studies reported in the literature. In PCOS, proinflammatory cytokines can damage the endothelial tissue with the emergence of the inflammatory process. As a result of this tissue damage, the number of mitochondria and the amount of VO2max might decrease $e^{(1,3,4,17,28,29)}$. VO2max is the maximum amount of oxygen the body can use during activity and is known as the best indicator of cardiovascular endurance. Only a few small studies are evaluated VO2max values in women with $\operatorname{PCOS}^{(3,4)}$. Thomson et al. ${ }^{(4)}$ found no difference in VO2max of women with and without PCOS who were overweight. Orio et al. ${ }^{(3)}$ assessed VO2max in overweight women with PCOS and found that overweight women with PCOS had lower VO2max values than overweight women without $\operatorname{PCOS}^{(3,15)}$. In our study, normal-weight women with PCOS had lower VO2max capacities than healthy women. We also found that the PCOS factor affects HDL-C and HOMA-IR values a relationship between HDL-C and VO2max. This result might indicate that IR and HDL-C factors affected myocardial and skeletal muscle metabolism. So, HOMA-IR and HDL-C should be regularly examined in PCOS, even at a normal weight. 
Table 4. Correlations between BAQ, SF-36, VO2max, and core stability test variables

\begin{tabular}{|c|c|c|c|c|c|c|c|c|c|c|c|}
\hline \multirow[b]{2}{*}{$\mathrm{VO} 2 \max$} & & \multicolumn{5}{|l|}{ PCOS } & \multicolumn{5}{|c|}{ Control } \\
\hline & & TFT & TEET & RBT & LBT & $\mathrm{VO} 2 \max$ & TFT & TEET & RBT & LBT & \\
\hline \multirow{2}{*}{ BAQ-total } & $\mathrm{r}$ & -0.079 & -0.131 & -0.223 & -0.035 & -0.092 & -0.084 & -0.144 & -0.009 & 0.032 & -0.162 \\
\hline & $\mathrm{p}$ & 0.581 & 0.359 & 0.115 & 0.808 & 0.520 & 0.563 & 0.317 & 0.949 & 0.828 & 0.260 \\
\hline \multirow{2}{*}{ BAQ-I } & $\mathrm{r}$ & -0.074 & -0.076 & -0.158 & 0.016 & -0.110 & -0.151 & -0.170 & -0.030 & -0.010 & -0.123 \\
\hline & $\mathrm{p}$ & 0.605 & 0.597 & 0.269 & 0.910 & 0.443 & 0.295 & 0.238 & 0.836 & 0.948 & 0.396 \\
\hline \multirow{2}{*}{ BAQ-II } & $\mathrm{r}$ & 0.268 & 0.241 & $0.286^{*}$ & -0.018 & -0.223 & -0.207 & -0.262 & -0.018 & -0.063 & -0.277 \\
\hline & $\mathrm{p}$ & 0.057 & 0.089 & 0.042 & 0.902 & 0.117 & 0.149 & 0.066 & 0.900 & 0.661 & 0.051 \\
\hline \multirow{2}{*}{ BAQ-III } & r & $-0.286^{*}$ & -0.089 & -0.015 & -0.151 & -0.078 & 0.113 & -0.071 & 0.012 & -0.118 & -0.159 \\
\hline & $\mathrm{p}$ & 0.042 & 0.535 & 0.916 & 0.289 & 0.584 & 0.436 & 0.623 & 0.933 & 0.413 & 0.269 \\
\hline \multirow{2}{*}{ BAQ-IV } & $\mathrm{r}$ & -0.275 & -0.098 & -0.239 & -0.195 & -0.179 & 0.051 & -0.027 & 0.013 & 0.114 & -0.050 \\
\hline & $\mathrm{p}$ & 0.051 & 0.494 & 0.091 & 0.170 & 0.210 & 0.724 & 0.853 & 0.929 & 0.432 & 0.729 \\
\hline \multirow{2}{*}{ Physical function } & $\mathrm{r}$ & -0.006 & -0.178 & 0.085 & -0.169 & -0.087 & 0.105 & $-0.337^{*}$ & 0.100 & 0.239 & $0.387^{* *}$ \\
\hline & $\mathrm{p}$ & 0.967 & 0.212 & 0.553 & 0.236 & 0.544 & 0.469 & 0.017 & 0.492 & 0.095 & 0.006 \\
\hline \multirow{2}{*}{ Physical role difficulty } & $\mathrm{r}$ & 0.111 & -0.096 & 0.040 & 0.088 & 0.200 & 0.246 & 0.249 & 0.152 & 0.157 & $0.324^{*}$ \\
\hline & $\mathrm{p}$ & 0.438 & 0.504 & 0.778 & 0.540 & 0.160 & 0.084 & 0.081 & 0.293 & 0.276 & 0.022 \\
\hline \multirow{2}{*}{$\begin{array}{l}\text { Emotional role } \\
\text { difficulty }\end{array}$} & $\mathrm{r}$ & -0.060 & 0.054 & 0.079 & -0.052 & 0.088 & -0.162 & 0.000 & -0.204 & 0.018 & -0.170 \\
\hline & $\mathrm{p}$ & 0.674 & 0.705 & 0.583 & 0.716 & 0.539 & 0.262 & 1.000 & 0.155 & 0.904 & 0.237 \\
\hline \multirow{2}{*}{ Vitality } & $\mathrm{r}$ & 0.152 & 0.239 & $0.387^{* *}$ & 0.190 & 0.260 & 0.008 & 0.114 & 0.008 & 0.002 & -0.037 \\
\hline & $\mathrm{p}$ & 0.288 & 0.091 & 0.005 & 0.182 & 0.065 & 0.957 & 0.430 & 0.954 & 0.990 & 0.801 \\
\hline \multirow{2}{*}{ Mental health } & r & $0.286^{*}$ & 0.270 & -0.015 & -0.166 & -0.113 & 0.115 & 0.018 & -0.091 & 0.232 & 0.198 \\
\hline & $\mathrm{p}$ & 0.042 & 0.055 & 0.915 & 0.245 & 0.431 & 0.428 & 0.904 & 0.529 & 0.105 & 0.167 \\
\hline \multirow{2}{*}{ Social function } & $\mathrm{r}$ & -0.008 & 0.112 & 0.003 & -0.122 & -0.101 & 0.098 & -0.004 & 0.179 & 0.129 & 0.133 \\
\hline & $\mathrm{p}$ & 0.956 & 0.432 & 0.981 & 0.394 & 0.479 & 0.497 & 0.980 & 0.213 & 0.374 & 0.355 \\
\hline \multirow{2}{*}{ Pain } & $\mathrm{r}$ & 0.254 & 0.177 & 0.214 & 0.098 & 0.237 & -0.054 & 0.176 & 0.140 & 0.086 & -0.048 \\
\hline & $\mathrm{p}$ & 0.072 & 0.214 & 0.131 & 0.492 & 0.094 & 0.709 & 0.220 & 0.333 & 0.553 & 0.738 \\
\hline \multirow[t]{2}{*}{ General health } & $\mathrm{r}$ & 0.218 & 0.037 & 0.226 & 0.273 & 0.058 & 0.018 & -0.184 & 0.049 & 0.239 & -0.030 \\
\hline & $\mathrm{p}$ & 0.124 & 0.798 & 0.110 & 0.053 & 0.688 & 0.903 & 0.202 & 0.736 & 0.095 & 0.838 \\
\hline
\end{tabular}

PCOS: Polycystic ovary syndrome, TFT: Trunk flexion test, TEET: Trunk extensor endurance test, LBT: Lateral left bridge test, RBT: Lateral right bridge test, BAQ: Body awareness questionnaire, BAQ-I (anticipation of bodily reactions); BAQ-II (sleep-wake cycle); BAQ-III (anticipation at the onset of the disease); and BAQ-IV (changes in body process), r: Spearman correlation

In addition to $\mathrm{VO} 2 \mathrm{max}$, muscle strength and endurance have also been shown to affect the risk of morbidity and mortality ${ }^{(8,9)}$. PCOS can alter muscle function through different metabolic and hormonal factors (such as hyperandrogenism, obesity, IR, HDL-C). Only two studies in the literature evaluated muscle strength in $\operatorname{PCOS}^{(4,5)}$. One study(t) found no difference in the muscle strength of women with and without PCOS who were overweight and ignored the effect of hyperandrogenism on muscle function. Another study ${ }^{(5)}$ found that women with PCOS had higher muscle strength than the control group. They stated that hyperandrogenism is effective in muscle strength in the study and attributed it to androgen hormones. Based on these studies, we included women with phenotype D-PCOS. So, we excluded women with hyperandrogenism. Our study found that normal-weight women with PCOS (phenotype D) had lower muscle endurance than control group women. This may indicate that WHR and IR are more important than other factors in damaging muscle function by slowing protein synthesis.

Body awareness is related to the perception of physical, psychosomatic, and autonomic changes in the body ${ }^{(12,13,30)}$. Alexander stated that while working on body awareness, 
Table 5. Effects of PCOS factor on biochemical parameters, VO2max, core endurance, BAQ, and SF-36 in the linear regression model

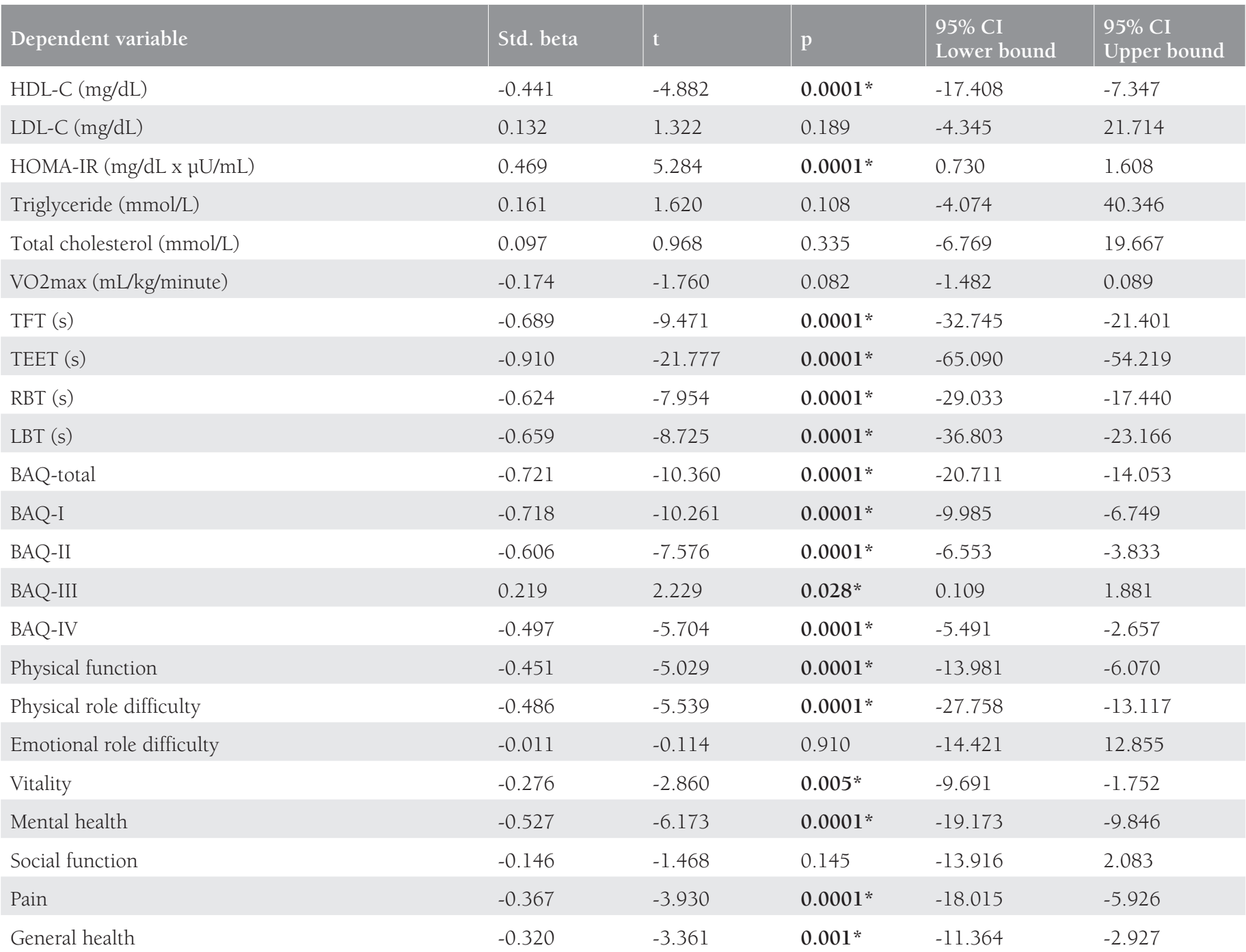

Std. beta: Standardized coefficients beta, CI: Confidence interval; univariate linear regression analysis

TFT: Trunk flexion test, TEET: Trunk extensor endurance test, LBT: Lateral left bridge test, RBT: Lateral right bridge test, WHR: Waist-hip ratio, HOMA-IR: Homeostatic model assessment for insulin resistance, s: Second, cm: centimeter, BAQ: Body awareness questionnaire, SF: Short-form, BAQ-I (anticipation of bodily reactions); BAQ-II (sleep-wake cycle); BAQ-III (anticipation at the onset of the disease) and $\wedge^{\wedge}$ BAQ-IV (changes in body process)

muscular changes can decrease the ability to receive information from the body ${ }^{(13)}$. To the best of our knowledge, there is no study in the literature evaluating body awareness in PCOS. In the present study, the body awareness of women with PCOS was lower than women without PCOS. VO2max and core endurance were also associated with body awareness parameters. These results may indicate that muscular and cardiovascular performance can be affected by changes in body awareness. This might suggest that providing body awareness training to women with PCOS in advanced studies might positively affect these parameters.

Body image deterioration and infertility can lead to selfconfidence and psychological problems, reducing the $\mathrm{QOL}^{(26)}$. The number of studies examining the effects of PCOS on QOL and its subscales is limited. Most studies found lower physical role function, pain, vitality, social function, emotional function, and mental health values in $\mathrm{PCOS}^{(31)}$. However, the cause-effect relationship remains unclear. Our results were similar to those reported in the literature. In other studies, the sole effect of PCOS on QOL could not be evaluated due to the obesity factor. Obesity itself is a concept that affects the QOL.

Physical function and physical role limitation subscales of SF36 in the present study also showed physical performance ${ }^{(31)}$. Core endurance and cardiovascular endurance are already indicators of physical performance. These subscales showed physical performance because cardiovascular endurance and core endurance are associated with these subscales. Also, there was a relationship between the psychological subparameter of SF-36 and VO2max in PCOS. This may indicate that mental well-being can positively affect aerobic performance.

The strength of the present study was that it was the first study to present a comprehensive summary of the parameters affected 
by PCOS in women of normal weight. Other strengths of the study were its adequate sample size, practical evaluation of the factors, and cost advantage. Also, another strength is the inclusion of only PCOS women with phenotype D for the study group.

\section{Study Limitations}

The present study had some limitations. One study limitation was that it did not analyze habitual physical activity levels for work and leisure. Also, nutritional habits and psychological problems could not be evaluated in detail. However, more detailed methods require more time. Also, long-term study protocols can reduce women' adaptability.

\section{Conclusion}

PCOS is among the most common endocrine disorders in the world. It is an important health problem that can significantly affect many factors. PCOS treatment and evaluation parameters have gained importance because of the chronic course of PCOS. In PCOS, the evaluation of parameters, such as aerobic capacity, muscular endurance, and QOL, can prevent potential negative problems. Also, determining the factors affected by PCOS may indicate that different approaches can be used as treatment options. According to phenotypes, future studies should investigate the effect of different exercise approaches on these parameters (muscle endurance, $\mathrm{VO} 2 \max$, body awareness, others).

\section{Ethics}

Ethics Committee Approval: Permission was granted from the Clinical Research Ethics Committee of the University before the study (decision no: 2017-KAEK-189_2020.01.08_04). All participants were informed about the study based on the 1975 Helsinki Declaration.

Informed Consent: All participants also signed informed consent that they agreed to participate in the study.

Peer-review: Internally peer-reviewed.

\section{Authorship Contributions}

Concept: H.D., M.M.Ç., Design: H.D., Data Collection or Processing: H.D., M.M.Ç., Analysis or Interpretation: M.M.Ç., Writing: H.D.

Conflict of Interest: The authors report no conflict of interest. Financial Disclosure: The authors have no financial interests about the research.

\section{References}

1. Wild RA, Carmina E, Diamanti-Kandarakis E, Dokras A, EscobarMorreale HF, Futterweit W, et al. Assessment of cardiovascular risk and prevention of cardiovascular disease in women with the polycystic ovary syndrome: a consensus statement by the androgen excess and polycystic ovary syndrome (AE-PCOS) society. J Clin Endocrinol Metab 2010;95:2038-49.

2. Almenning I, Rieber-Mohn A, Lundgren KM, Løvvik TS, Kirsti KG, Moholdt T. Effects of high intensity interval training and strength training on metabolic, cardiovascular and hormonal outcomes in women with polycystic ovary syndrome: a pilot study. PLoS One 2015;10:e0138793. doi: 10.1371/journal.pone.0138793.

3. Orio F Jr, Giallauria F, Palomba S, Cascella T, Manguso F, Vuolo L, et al. Cardiopulmonary impairment in young women with polycystic ovary syndrome. J Clin Endocrinol Metab 2006;91:296771.

4. Thomson RL, Buckley JD, Moran LJ, Noakes M, Clifton PM, Norman RJ, et al. Comparison of aerobic exercise capacity and muscle strength in overweight women with and without polycystic ovary syndrome. BJOG 2009;116:1242-50.

5. Kogure GS, Silva RC, Picchi Ramos FK, Miranda-Furtado CL, Lara LA, Ferriani RA, et al. Women with polycystic ovary syndrome have greater muscle strength irrespective of body composition. Gynecol Endocrinol 2015;31:237-42.

6. Tuttle CSL, Thang LAN, Maier AB. Markers of inflammation and their association with muscle strength and mass: a systematic review and meta-analysis. Ageing Res Rev 2020;64:101185. doi: 10.1016/j. arr.2020.101185

7. Landén NX, Li D, Ståhle M. Transition from inflammation to proliferation: a critical step during wound healing. Cell Mol Life Sci 2016;73:3861-85.

8. García-Hermoso A, Agostinis-Sobrinho C, Camargo-Villalba GE, González-Jiménez NM, Izquierdo M, Correa-Bautista JE, et al. Normal-weight obesity is associated with poorer cardiometabolic profile and lower physical fitness levels in children and adolescents. Nutrients 2020;12:1171.

9. Datta A, Sen S, Shivpriya S. Effects of Core Strengthening on Cardiovascular Fitness, Flexibility and Strength on Patients with Low Back Pain. J Nov Physiother 2014;4:1-6.

10. Abdallah AA, Mohamed NA, Hegazy MA. A Comparative study of core musculature endurance and strength between soccer players with and without lower extremity sprain and strain injury. Int J Sports Phys Ther 2019;14:525-36.

11. Kite C, Lahart IM, Afzal I, Broom DR, Randeva H, Kyrou I, et al. Exercise, or exercise and diet for the management of polycystic ovary syndrome: a systematic review and meta-analysis. Syst Rev 2019;8:51.

12. Ribeiro VB, Kogure GS, Silva RC, Souza HCD, Ferriani RA, dos Reis RM. Increased sympathetic cardiac autonomic modulation after two consecutive tilt tests in women with polycystic ovary syndrome. Rev Bras Ginecol Obstet 2020;2:81-9.

13. Erden A, Altuğ F, Cavlak U. Investigation of the Relationship between Body Awareness Status and Pain, Emotional State and Quality of Life in Healthy People. The Journal of Kartal Training and Research Hospital 2013;24:145-50.

14. Montazeri A, Goshtasebi A, Vahdaninia M, Gandek B. The Short Form Health Survey (SF-36): translation and validation study of the Iranian version. Qual Life Res 2005;14:875-82.

15. Hoeger KM. Obesity and lifestyle management in polycystic ovary syndrome. Clin Obstet Gynecol 2007;50:277-94.

16. Turner-McGrievy G, Davidson CR, Billings DL. Dietary intake, eating behaviors, and quality of life in women with polycystic ovary syndrome who are trying to conceive. Hum Fertil (Camb) 2015; 18:16-21

17. Orio F, Muscogiuri G, Nese C, Palomba S, Savastano S, Tafuri D, et al. Obesity, type 2 diabetes mellitus and cardiovascular disease risk: an uptodate in the management of polycystic ovary syndrome. Eur J Obstet Gynecol Reprod Biol 2016;207:214-9.

18. Cosar E, Köken G, Sahin FK, Akgün L, Uçok K, Genç A, et al. Resting metabolic rate and exercise capacity in women with polycystic ovary syndrome. Int J Gynaecol Obstet 2008;101:31-4. 
19. Rotterdam ESHRE/ASRM-Sponsored PCOS Consensus Workshop Group. Revised 2003 consensus on diagnostic criteria and longterm health risks related to polycystic ovary syndrome. Fertil Steril 2004;81:19-25.

20. Dehghani Firoozabadi A, Dehghani Firouzabadi R, Eftekhar M, Sadat Tabatabaei Bafghi A, Shamsi F. Maternal and neonatal outcomes among pregnant women with different polycystic ovary syndrome phenotypes: A cross-sectional study. Int J Reprod Biomed 2020;18:339-46.

21. Hizal A, Açıkada C, Hazır T, Tınazcı C. Reliability and validity of modified shuttle run test. Hacettepe J. of Sport Sciences 1997;4:312.

22. Visier-Alfonso ME, Sánchez-López M, Martı́nez-Vizcaíno V, Jiménez-Lopez E, Redondo-Tébar A, Nieto-Lopez M. Executive functions mediate the relationship between cardiorespiratory fitness and academic achievement in Spanish school children aged 8 to 11 years. PloS One 2020;15:e231246. doi: 10.1371/journal. pone. 0231246015 .

23. Léger LA, Lambert J. A maximal multistage 20-m shuttle run test to predict VO2max. Eur J Appl Physiol Occup Physiol 1982;49:1-12.

24. McGill SM, Childs A, Liebenson C. Endurance times for low back stabilization exercises: clinical targets for testing and training from a normal database. Arch Phys Med Rehabil 1999;80:941-4.
25. Özmen T, Gafuroğlu Ü, Aliyeva A, Elverici E. Relationship between core stability and dynamic balance in women with postmenopausal osteoporosis. Turk J Phys Med Rehab 2018;64:239-45.

26. Shields SA, Mallory, ME, Simon A. The body awareness questionnare reliability and validity. J Pers Assess 1989;53:802-15.

27. Karaca S, Bayar B. Turkish version of body awareness questionnaire: validity and reliability study. Turk J Physiother Rehabil 2021;32:4450 .

28. Koçyiğit H, Aydemir Ö, Fişek G, Ölmez N, Memiş A. Validity and reliability of Turkish version of short form 36. İlaç ve Tedavi Dergisi 1999; 12:102-6

29. Mayorga-Vega D, Aguilar-Soto P, Viciana J. Criterion-related validity of the 20-m shuttle run test for estimating cardi-orespiratory fitness: a meta-analysis. J Sports Sci Med 2015;14:536-47.

30. Mehling WE, Gopisetty V, Daubenmier J, Price CJ, Hecht FM, Stewart A. Body Awareness: Construct and Self-Report Measures. PLoS One 2009;4:e5614. doi: 10.1371/journal.pone.0005614.

31. Hahn S, Janssen OE, Tan S, Pleger K, Mann K, Schedlowski M, et al. Clinical and psychological correlates of quality-of-life in polycystic ovary syndrome. Eur J Endocrinol 2005;153:853-60. 